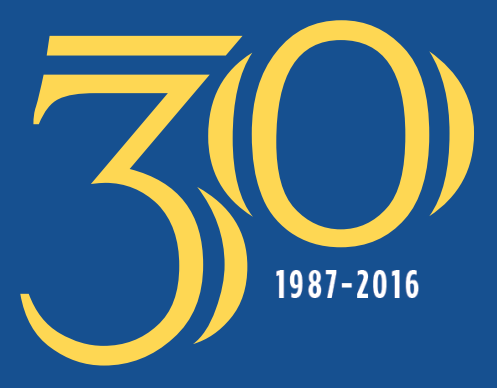

Ethics

International

Affairs

VOLUME $30 \cdot$ NUMBER 3 •FALL 2016

\title{
Ethics and Inequality:
}

\section{A Strategic and \\ Practical View}

James K. Galbraith

\section{ESSAYS}

Climate Contributions and the Paris Agreement:

Fairness and Equity in a Bottom-Up Architecture

Nicholas Chan

Recognition: A Short History

Jens Bartelson

Swedish Feminist Foreign

Policy in the Making:

Ethics, Politics, and Gender

Karin Aggestam and

Annika Bergman-Rosamond

F EATUR ES

Self-Interest and the Distant Vulnerable Luke Glanville
Should International Courts Use Public Reason?

Silje Aambø Langvatn

\section{RESPONSE}

Robots and Respect:

A Response to Robert Sparrow

Ryan Jenkins and Duncan Purves

\section{REVIEWS}

Realpolitik: A History

John Bew

Review by Michael C. Williams

Can Microfinance Work?

How to Improve Its Ethical Balance and Effectiveness

Lesley Sherratt

Review by Jonathan Morduch 


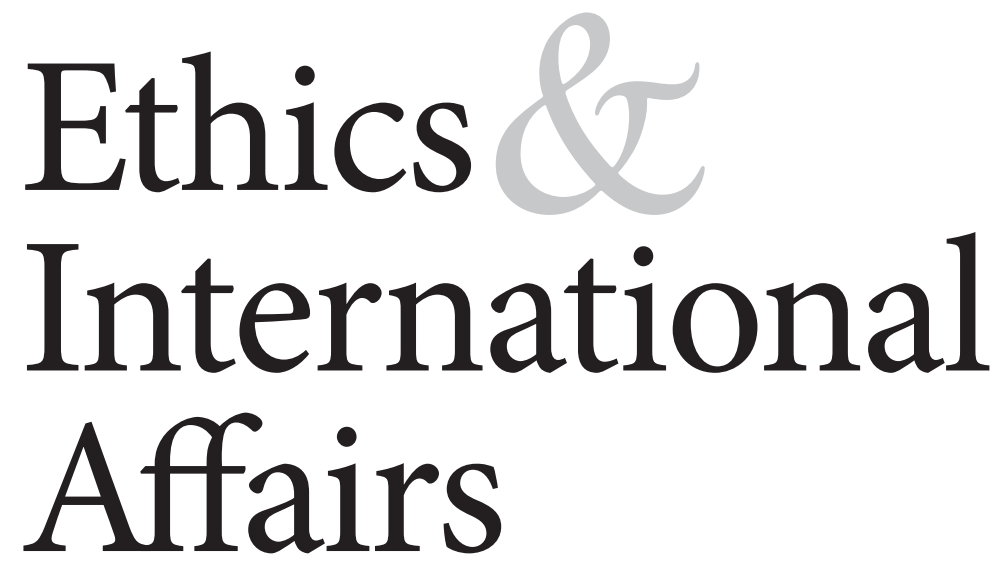

VOLUME $30 \cdot$ NUMBER $3 \cdot$ FALL 2016

\section{CARNEGIE}

The Voice for Ethics

in International Affairs 


\title{
Ethics \& International Affairs
}

THE JOURNAL OF THE CARNEGIE COUNCIL

\author{
EDITOR IN CHIEF Joel H. Rosenthal \\ EDITOR John Tessitore \\ DEPUTY EDITOR/MANAGING EDITOR Zornitsa Stoyanova-Yerburgh \\ ASSISTANT EDITOR Adam Read-Brown \\ EDITORIAL FELLOW Tina Cai \\ COPY EDITOR Meghan Lynn \\ BUSINESS MANAGER Eva Becker
}

EDITORIAL ADVISORY BOARD

$\begin{array}{lll}\text { Christian Barry } & \text { Nikolas Gvosdev } & \text { David Rodin } \\ \text { Alex J. Bellamy } & \text { Ian Hurd } & \text { S. Prakash Sethi } \\ \text { Allen Buchanan } & \text { Anthony F. Lang, Jr. } & \text { Henry Shue } \\ \text { Deen K. Chatterjee } & \text { Anthony Langlois } & \text { Jennifer Welsh } \\ \text { Robyn Eckersley } & \text { David Luban } & \text { Leif Wenar } \\ \text { Ann Florini } & \text { David R. Mapel } & \\ \text { Joy Gordon } & \text { Darrel Moellendorf } & \end{array}$

\section{Carnegie Council for Ethics in International Affairs}

The Carnegie Council for Ethics in International Affairs is an independent, nonpartisan, nonsectarian, tax-exempt organization founded in 1914 by Andrew Carnegie. Since its beginnings, the Carnegie Council has asserted its strong belief that ethics, as informed by the world's principal moral and religious traditions, is an inevitable and integral component of all policy decisions, whether in the realm of economics, politics, or national security. The interrelationship of ethics and foreign policy is thus the unifying theme of all Carnegie Council programs. By promoting a greater understanding of the values and conditions that ensure peaceful relations among nations, the Carnegie Council hopes to contribute to a better life for people everywhere.

BOARD OF TRUSTEES

Kathleen Cheek-Milby

Niovi Christopolou

Jonathan E. Colby

Barbara Crossette

Michael W. Doyle

Richard A. Edlin,

Treasurer

Jonathan Gage
Stephen D. Hibbard,

Vice Chairman

Haris Hromic

Bruce W. Jentleson, Vice Chairman

Zachary Karabell

Susan King

Violy McCausland-Seve
Amir Pasic

Joel H. Rosenthal, President

Robert G. Shaw, Chairman

Michael J. Smith

Robert P. Smith

James $P$. Wind

HONORARY TRUSTEE Maurice S. Spanbock, Esq. INTERNATIONAL HONORARY TRUSTEE Eiji Uehiro 


\section{Contents}

Contributors 287

ESSAYS Climate Contributions and the Paris Agreement: Fairness and Equity in a Bottom-Up Architecture

Nicholas Chan 291

Recognition: A Short History

Jens Bartelson 303

Swedish Feminist Foreign Policy in the Making: Ethics, Politics, and Gender

Karin Aggestam and Annika Bergman-Rosamond 323

FEATURES Self-Interest and the Distant Vulnerable Luke Glanville 335

Should International Courts Use Public Reason?

Silje Aambø Langvatn 355

REVIEW ESSAY Ethics and Inequality: A Strategic and Practical View James K. Galbraith 379

RESPONSE Robots and Respect: A Response to Robert Sparrow Ryan Jenkins and Duncan Purves 391

Robots as "Evil Means"? A Rejoinder to Jenkins and Purves Robert Sparrow 401

REVIEWS Realpolitik: A History

John Bew

Review by Michael C. Williams 405

Can Microfinance Work? How to Improve Its Ethical Balance and Effectiveness

Lesley Sherratt

Review by Jonathan Morduch 408

Briefly Noted 411

SUBMISSIONS Guidelines for Submission 413

RESOURCES For additional Carnegie Council resources on the topics addressed in these pages, please visit www.ethicsandinternationalaffairs.org. 
ETHICS \& INTERNATIONAL AFFAIRS (ISSN 0892-6794 print; ISSN 1747-7093 online).

\section{Publisher}

Ethics \& International Affairs is published quarterly by Cambridge University Press,

One Liberty Plaza, 2oth floor, New York, NY 10006.

Information for subscribers

Ethics \& International Affairs is published in four issues per year. Institutional subscription prices for 2016 are: Print \& Online: US \$534 in the USA, Canada, and Mexico; UK $\mathfrak{E}_{328}+$ VAT elsewhere. Institutions electronic only: US\$477 in the USA, Canada, and Mexico; UK£290 + VAT elsewhere. Individuals print only: US\$43 in the USA, Canada, and Mexico; UK£29 + VAT elsewhere. Correspondence concerning subscriptions should be sent to: Cambridge University Press, One Liberty Plaza, 2oth floor, New York, NY, USA for customers in the USA, Canada, or Mexico. Customers elsewhere should contact: Cambridge University Press, The Edinburgh Building, Shaftesbury Road, Cambridge $\mathrm{CB}_{2}$ 8RU, UK. The price includes online access to the current and all online back files to January 1st 1997, where available.

\section{Delivery Terms and Legal Title}

Prices include delivery of print journals to the recipient's address. Delivery terms are Delivered Duty Unpaid (DDU); the recipient is responsible for paying any import duty or taxes. Legal title passes to the customer on despatch by our distributors.

Production Editor: Diane Davis (email: ddavis@cambridge.org).

Electronic Access Access to this journal is available free online within institutions in the developing world through the AGORA initiative with the FAO, the HINARI initiative with the WHO and the OARE initiative with UNEP. For information, visit www.aginternetwork.org, www.healthinternetwork.org, www.oarescience.org. Abstracting and Indexing Services The Journal is indexed by Academic Search (EBSCO), Academic Search Premier (EBSCO), CSA Environmental Sciences \& Pollution Management Database (CSA/CIG), CSA Sustainability Science Abstracts (CSA/CIG), Current Abstracts (EBSCO), Current Contents ${ }^{\circledast} /$ Social and Behavioral Sciences (Thomson Reuters), Expanded Academic ASAP (Thomson Gale), IBSS: International Bibliography of the Social Sciences (LSE), InfoTrac, International Political Science Abstracts (IPSA), Journal Citation Reports/ Social Sciences Edition (Thomson Reuters), OMNIFILE Full Text Mega Edition (OMNIFILE), PAIS: Public Affairs Information Service (CSA/CIG), Proquest 5000 (ProQuest), Proquest Discovery (ProQuest), Proquest Platinum (ProQuest), Proquest Research Library (ProQuest), Proquest Social Science Journals (ProQuest), Social Sciences Citation Index ${ }^{\infty}$ (Thomson Reuters), Social Sciences Index/Abstracts (HW Wilson), Student Resource Center College (w/ Academic ASAP),Wilson OMNIFILE Full Text Select (HW Wilson) and Worldwide Political Sciences Abstracts (CSA/CIG).

Disclaimer The Publisher, Carnegie Council, and Editors cannot be held responsible for errors or any consequences arising from the use of information contained in this journal; the views and opinions expressed do not necessarily reflect those of the Publisher, Council and Editors, neither does the publication of advertisements constitute any endorsement by the Publisher, Council and Editors of the products advertised.

Copyright and Photocopying Copyright (C) 2016 Carnegie Council for Ethics in International Affairs. All rights reserved. No part of this publication may be reproduced, in any form or by any means, electronic, photocopying, or otherwise, without permission in writing from Cambridge University Press. Policies, request forms, and contacts are available at: http://www.cambridge.org/rights/permissions/permission.htm Permission to copy (for users in the U.S.A.) is available from Copyright Clearance Center, http://www.copyright.com, email: info@copyright.com.

Printed in USA by The Sheridan Press.

View this journal online at journals.cambridge.org/EIA.

ISSN 0892-6794 (Print)

ISSN 1747-7093 (Online) 


\section{Ethics \& International Affairs}

